Volume: 11 Issue: 1 Year: 2014

\title{
The analysis of social capital and social networking of drug trafficking ${ }^{1}$
}

\author{
Hamdi Yeşilyurt ${ }^{2}$
}

\begin{abstract}
Transnational organized crime (TOC), such as drug trafficking, has been a sustained problem for society because of the visible impact on drug abuse that is evident in media coverage. However, research on the development of drug trafficking organizations through clandestine social networks has been limited. Consequently, this study applies Social Network Theory to significant aspects of drug trafficking-business economics and social networks inside drug trafficking groups. The analysis identifies similarities between the legal business and criminal organizations that can lead to favorable methods of criminal justice intervention.
\end{abstract}

Keywords: Social Network, Drug Trafficking, Social Capital, Drug Cartels, Business, Crime.

\section{Introduction}

The global war on drugs has not succeeded (Williams, 1998; United Nations Office on Drugs and Crime, 2013). The use of psychoactive substances is on the rise while traditional drug use has not diminished (UNODC, 2013). The risk associated with penetrating the underground organizations certainly contributes to the limited research on the nature of social networks and social capital regarding drug trafficking groups. Though researchers have focused on different networking aspects of drug trafficking groups (Williams, 1998; McIllwain, 1999; Grootaert \& Van Bastelaer, 2002; Kenney, 2007; Morselli, 2009), how drug trafficking groups are networked, continue their business and increase social capital has been relatively undocumented. This failure can be rooted in misunderstanding the social network structure of drug trafficking organizations (Williams, 1998) and the methods to stop drug abuse (Kappeler \& Potter, 2005). This study digs into different facets of drug trafficking networks, determines common traits that characterize a

\footnotetext{
1 Yesilyurt, Hamdi. "The Analysis of Social Network and Business like Structures of Transnational Organized Crime" Paper presented at the annual meeting of the ASC Annual Meeting, St. Louis Adam's Mark, St. Louis, Missouri, Nov 11, 2008

2 Ph.D., Turkish National Police, hamdi.yesilyurt@egm.gov.tr
} 
Yeşilyurt, H. (2014). The analysis of social capital and social networking of drug trafficking. International Journal of Human Sciences, 11(1), 280-290. doi: 10.14687/ijhs.v11i1.2758

TOC, and then identifies the similarities and differences from the perspective of legal business expansion utilizing social capital.

\section{Definitions and Background}

Drugs are physical substances that have both therapeutic and toxic properties. Therefore, drugs can help treat disease or represent immoral use based on their relation to moral values and principles set by society. Most dictionaries define drugs as substances used in medication, but the medical aspects of drugs have been overshadowed by their illegality (Gaines \& Kraska, 2003). Illicit drug distribution has been considered a major threat and harmful due to their adverse effects on individuals, regions and global society (Degenhardt \& Hall, 2012; Kucukuysal, 2012; UNODC, 2013; Fukumi, 2013;). The major pillars of illicit drug business — drugs, gangs and violence further compound the social harm from illicit drug distribution (National Drug Assessment, 2011)

One of the most lucrative businesses of organized crime is drug trafficking (Andreopoulos, 2013). The United States is a prime destination point for many drug trafficking groups established in Mexico, Columbia, the Dominican Republic and Cuba. Ethnic groups, such as those from Asia, also play a significant role in targeting the highly profitable US market. Factors contributing to the penetration of drug trafficking in the US include multiple opportunities to access large borders by air, sea, and unguarded territorial border using a network of underground tunnels and ultra-light aircraft that are able to overcome detection by conventional radar (National Drug Intelligence Center, 2011).

Casteel (2001) and National Drug Intelligence Center (2011) describes how different criminal groups traffic and distribute illegal drugs. He traces the origin of cocaine and heroin destined for the U.S. to criminal groups operating from South America. The success of these illicit drug supply chains have been attributed to the diversity of routes-land routes through Mexico, marine routes along Mexico's east and western coastlines, sea routes through the Caribbean, and worldwide air passageways. Illegal groups located in Mexico have transported cocaine, heroin, methamphetamines, amphetamines, and marijuana across the southwest U.S. border since the 1970s. Since that time, Mexico-based groups have expanded the delivery of cocaine and methamphetamines throughout the Midwest and into eastern U. S. marketplaces. The extent of the illicit drug penetration can only be estimated. However, cocaine seizures in the U. S. (94 tons) and Colombia (200 tons) described in the UNODC World Drug Report (2012) as higher than countries in the world, demonstrate the alarming scope of the problem.

Clearly, criminal activity of this magnitude requires the formation of organized crime syndicates capable of developing extensive supply chains. Networking is an acceptable method to 
disseminate knowledge to bring changes in organizations which can optimize restricted resources (Sellen, 2009). But in order to understand the development of these vast enterprises, Potter (1993) proposed that it is useful to analyze organized crime syndicates in network terms. McIllwain (1999) concurs that the structure of ties determines the fundamental nature of organized crime syndicates. Morselli (2009) added that criminal activity can be examined through the lens of legal business activity. Integrating these insights from social networking and social capital, this study focuses on social network structure of organized crime syndicates, including their business structure and social capital in the knowledge economy.

\section{Social Networks and Drug Trafficking}

Drug trafficking is based on transferring goods in an illegal way, including offences against individuals and the government. Drug trafficking is a form of crime that includes business-like activities with an emphasis on large earnings. High profits, perhaps the most critical element of drug trafficking, entice members with the hope of a higher quality of life despite the violence, corruption, and potential loss of life that are fundamental outcomes when drug cartels must overcome resistance (Albanese, 2004). Individuals are lured to criminal organizations because of the perceived advantages of reduced risk by association. To members, organized crime cartels are not just a criminal group but act as a protective social group to resist opposition that threatens their survival (Abadinsky, 2010). As a result, the examination of social networks and drug trafficking represent a specific, structured community with pre-determined roles and limited leadership.

In general, the fundamental concern of sociology is to examine social structure while maintaining sensitivity to existing structural limitations (Wellman, 1983). Wasserman \& Faust (1994) conclude that that a social network is a sort of analysis that is focused on relationships among particular social entities and patterns. . Ultimately, the purpose of network analysis is to determine how structural properties influence actions outside of the effects of standard solutions, individual attributes, and reciprocal relationships. For example, the best way to examine social systems is to question the design of ties connecting its associates. Analyzing complex structures of asymmetric ties grant ability to research on power, stratification, and structural change for sociologists.

Wellman (1983) states that structural form of a network influence the dissemination of resources through specific ties. Wasserman \& Faust (1994, p. 4-5) describe the unit of analysis as the individual actors versus a collection of actors and provides the assumptions of a social network:

- relationships are a basic component,

- actors and their actions are interrelated (not isolated), 
- relational ties are a channel for the flow of resources,

- network structure are opportunities or constraints of individual actions, and

- structure are lasting patterns of relationships.

The focus of social network analysis is especially characteristic of isolated individuals vs. linkages among units. Another focus of social network analysis is patterns of relationships that give elevation to structure where relational ties are primary and attributes of actors are secondary.

\subsection{Expansion of Social Networks}

The size of social network is an essential consideration because formation and expansion of a network is dependent on adding contacts to the network. Efficiency and effectiveness of network expansion is an important factor to obtain information for both drug trafficking groups and legal businesses. Cross, Parker \& Sasson (2003) states that larger and diverse networks have greater benefits in regard to information than small and homogenous networks. The literature indicates "bigger is better" as the ability to add more contacts is advantageous for existing network members. In an ordinary network, developing and adding relations is usually similar to Figure 1. In Figure 1, the initial network on the left side is composed of four contacts. As more contacts are introduced, the final network on the right grows to sixteen contacts. Therefore, doubling effect can be seen in network B and snowballing in network C. However, the expansion in the Figure 1 is not complex as there is no effort to optimize network communication or reduce the costs of knowledge sharing.

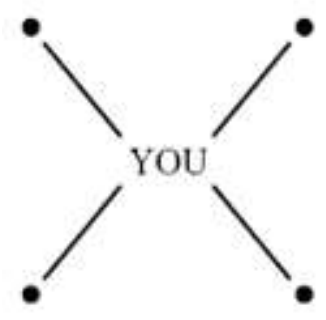

Network A

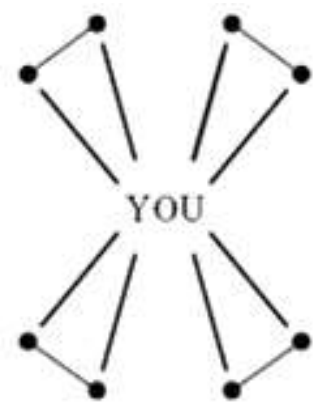

Network B

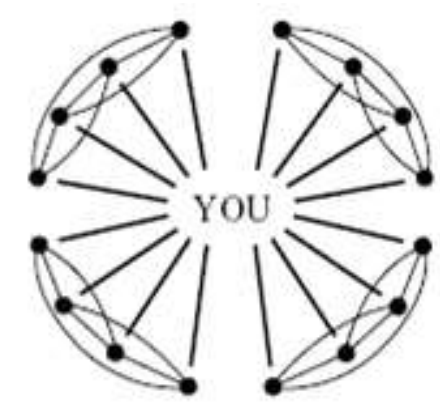

Network C

Figure 1. Basic Network Expansion (Cross, Parker \& Sasson, 2003)

The network expansion shown in Figure 1 is a basic network structure. However, generating efficiency is a key factor in network optimization (Cross, Parker \& Sasson, 2003). Therefore, taking action to remove redundant contact information among members may save time and reduce operating costs.

Efficient enlargement of network is shown in Figure 2. In this example, Network C reaches the same number of people similar to the Figure 1. However, this is achieved as Network C 
decreases the cost of maintaining contact information in the network resulting in more direct ties. Wellman (1983) indicates that networks structured to reach group members directly are advantageous over those networks where members are linked indirectly (Figure 1).

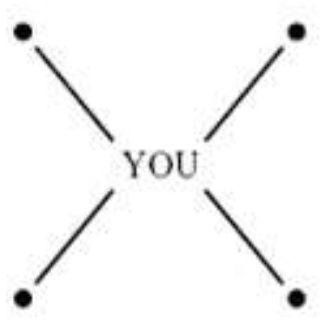

Network $\mathbf{A}^{\prime}$

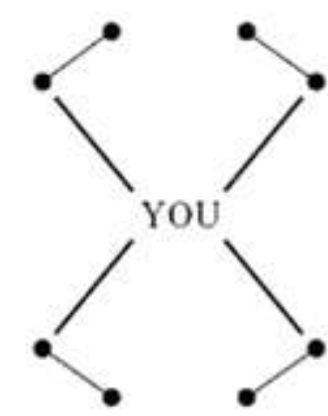

Network B'

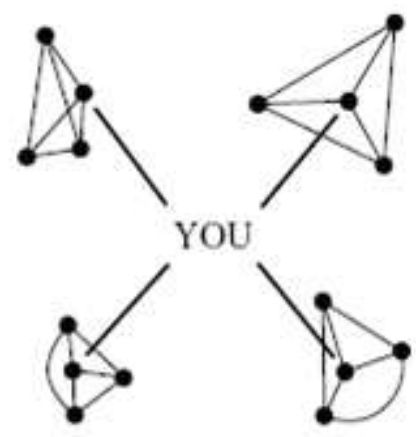

Network $\mathrm{C}^{\prime}$

Figure 2. Social Network Expansions

Even though larger networks provide higher paying positions to individuals participating in the network than small networks (Flap \& Boxman, 2001), large networks are not advantageous for drug cartels. Indeed, “....small-sized groups can adapt well to ever changing market constraints and uncertainties. They have little vertical bureaucratic structure, even though their operations may involve highly specialized tasks" (Zhang \& Chin 2004, p. 478). Hence, the major difference between legal organizations and criminal organizations is that big size is preferable for social capital in legal networks while drug cartels prefer smaller networks.

Criminal groups expand their network in order to be more successful in the illegal business of drug trafficking business(Kenney, 2007) but the size of organized crime syndicates may vary depending on existing opportunities (Albanese, 2004). Often, members of drug cartels try to expand their networks through personal relationships (Abadinsky, 2010) by recruiting acquaintances, relatives and family members (Kenney, 2007). Organized crime groups also use social network and web sites such as MySpace, Twitter, and YouTube to entice recruits with images portraying a satisfactory organized crime lifestyle (Harris, 2010). However, contrary to expansion, participation in drug business usually ends with the removal of a member (Morselli, 2009). In legal business, removal of an employee is quite harder due to compensation and job security regulations.

\section{2. $\quad$ Strength of Ties}

Granovetter (1982) elucidates three different types of social networks in his "Strength of Weak Ties" theory: strong, weak and absent. Wellman (1983), mentions that "the stronger the tie connecting two individuals, the more similar they are, in various ways" (p. 1364). Wellman also states that if there is a strong tie between $\mathrm{A}$ to $\mathrm{B}$ and $\mathrm{A}$ to $\mathrm{C}$, both $\mathrm{C}$ and $\mathrm{B}$, being similar to $\mathrm{A}$, are probably akin to one another, rising the probability of a friendship once they have met. If there is a 
tie between A-B and A-C but not relationship between $\mathrm{C}-\mathrm{B}$, this condition is called a forbidden tie as shown in Figure 3.

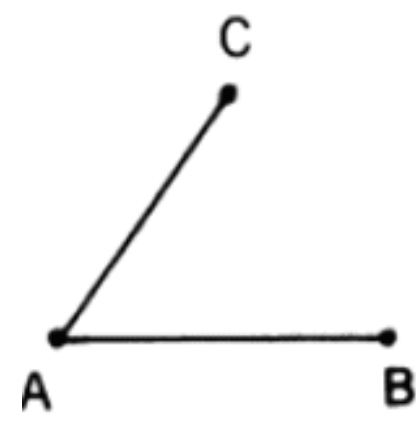

\section{Figure 3. Forbidden Triad}

The similarities between actors might bring many advantages in terms of knowledge sharing within the group but high similarity might also cause disadvantages. The one who has weak ties with many other groups is more likely to get different information from others. For example the more he/she has weak ties, the more likely the individual will have access to new or different information, such as finding a job vacancy (Jackson et al. , 1996).

Networking helps crime syndicates' members obtain information and exchange their experience and knowledge resources in order to facilitate the crime business (Calvó-Armengol \& Zenou, 2004). Many of the criminal organizations are loose and temporary, that is, their hierarchical structures are in the minority. Organized crime is progressively operating through fluid network structures rather than more formal hierarchies. Even Italian organized crime in the United States could best be comprehended through patron-client relations rather than formal hierarchies (Abadinsky, 2010; Williams, 1998). As such, relationships are usually based on agreement in organized crime groups (Arias, 2006). However, when motivation is profit for the members of the organization, strong hierarchical systems prevent sharing knowledge (Williams, 1998). The location of the player's links in organization's structure and specifically the structure of the actor's network determines a competitive advantage in obtaining higher rates of return on investment (Cross, Parker \& Sasson, 2003).

\section{Social Capital and Business in Drug Trafficking Organizations}

Social capital has become an important topic of interest by scholars and can be in the form of information sharing and networking based on mutual benefit (Grootaert \& Van Bastelaer, 2002). While there is little consensus on the definition of the concept (Putnam, 2002), there is an agreement on its use for the good of society, and harms emanating from criminal groups that utilize social capital and social networking for criminal purposes (Putnam, 2002). Capital has a value in 
Yeşilyurt, H. (2014). The analysis of social capital and social networking of drug trafficking. International Journal of Human Sciences, 11(1), 280-290. doi: 10.14687/ijhs.v11i1.2758

favor of society and the loss of social capital undermines society as declining civic engagement may threaten the democratic standards (Putnam, 2000).

Social networks in business economics concentrate on a specific aim or on the supply of a specific product. Social networks also concentrate on a variety of products in more diverse activities. Likewise, criminal networks have the same notion. For example, Colombian and Mexican drug cartels are specifically concentrated on the illegal drug business and little else. In contrast, Russian and Chinese crime syndicates have quite diverse portfolio of criminal activities (Williams, 1998). However this concentration does not mean that they have solidarity in the drug trafficking business. On the contrary, cocaine production and smuggling is performed in the hands of many criminal groups in a competitive arena, including the export of large amounts of drug to the U.S. and Europe (Kenney, 2007).

For any type of criminal or other type of network, social ties are essential to reach required resources and to achieve goals (Lin, 2002). Social networking leverages ties and transactions for crime syndicates because it brings more opportunities for cooperation (Abadinsky, 2010). Through these ties, organized crime has found operating locations around the world under multiple financial and political systems (Mishra, 2008). This expansion has facilitated the spread of drug trafficking while undermining economics and the administration of governments (Andreopoulos, 2013). However, drug trafficking organizations have built their own social capital by using practices similar to government such as determining obligations of both upper and lower level members (Abadinsky, 2010). Provided that commitments are fulfilled by members, social networking decreases susceptibility and insecurities in an unfamiliar environment for organized crime groups (Calvó-Armengol \& Zenou, 2004) that help to maintain the organization.

Another aspect of social networking is competition, which is very important in social networks and legal business. The key point in the social structure arena is the rate of return. Every actor has a network of contacts in the platform (Cross, Parker \& Sasson, 2003). For organized criminals two things are critical: 1) resources that can be accessible by criminal groups and, 2) the possibility that those resources could cause emergence of new criminal syndicates. In essence, access to illegal markets, industry and geographic locations suffering economic and political problems helps to establish criminal networks. Nonetheless, even these newly formed networks only survive if opportunities exist (Morselli \& Turcotte, 2010).

Networks are sustained by three types of social capital that could be brought to the competitive arena by a player. First, "cash in hand, reserves in the bank, investments coming due, lines of credit' (Cross, Parker \& Sasson, 2003, p. 13). Therefore, drug dealers' endeavor to sell as much volume at a price point that is acceptable to consumers. When the worth of illicit drugs rises, fewer 
customers will be able to pay that price. At that point, some customers will switch to other drugs, including permissible alcohol. Others, particularly "dabblers" who have not developed an addiction, will discontinue paying for drugs. In the case of legal commodities as in illegal items, a supply and demand exists, which is affected by price. To sum up, supply equals demand at a given price (Gaines \& Kraska, 2003). Secondly, "natural qualities_charm, health, and intelligence” of the actor can increase human capital; thirdly, the actor has social capital: relationships with other actors (Cross, Parker \& Sasson, 2003, p. 13). The social capital of organizations is collective for the social capital of people (Cross, Parker \& Sasson, 2003) in that any friend or colleague of a member can represent an opportunity for financial and human capital in the organization. Criminal organizations utilize investments, natural qualities, and affairs with others to improve their capital. The actual difference between business organizations and criminal organizations is their goal as criminal organizations seek to increase their own benefit at higher risks, involving crime and violence.

The production capacity of an organization is dependent on property and human assets. However, no one has direct exclusive rights to social capital. The connection is bound to partnerif a partner withdraws, the social capital in the network fails. For instance, if a firm does not treat its customers well, than the customer-firm relationship has the potential to vanish (Cross, Parker \& Sasson, 2003). Similarly, drug traffickers also need to treat their customers well in the drug bazaar. For example, if a dealer sells low quality heroin, then the customer-seller relationship might be broken. Likewise, criminal organizations sell goods and expect a sufficient return on their investment.

\section{Benefit-Rich Networks and Business Like Structures of Drug Trafficking Organizations}

"The information benefits of a network define who knows about these opportunities, when they know, and who gets to participate in them" (Cross, Parker \& Sasson, 2003, p. 18). An actor who participates in a network rich in information focuses on consistent information that he/she could capture in the environment from a trustworthy resource. Trusting the right person is the key point in business networks. On the criminal network's side, mutual respect is also important; however, most of the time trust can be broken based on short-term interest that leads to failure. Moreover, criminal groups can benefit from business as long as they are not targeted by police. If they do not feel secure in their environment, they may move to a different location and change their primary business (Williams, 1998). Thus, short-term interest oriented relations are evident for drug syndicates. 
Yeşilyurt, H. (2014). The analysis of social capital and social networking of drug trafficking. International Journal of Human Sciences, 11(1), 280-290. doi: 10.14687/ijhs.v11i1.2758

Access, timing, and referrals are three types of information benefits. Access is defined as "receiving a valuable piece of information and knowing who can use it" (Cross, Parker \& Sasson, 2003, p. 18 while timing is one of the significant parts of information received by the network. Being informed early by personal contacts is very crucial (Cross, Parker \& Sasson, 2003). For both of the organization types, access, timing and referrals are quite important. For instance if criminal organization is informed early that a new illicit drug trade is going to be started by a rival group, then the criminal organization might prepare for the new trade in the drug bazaar. Therefore, access to such contacts and timing is favorable for both business economics and drug cartels.

\section{Conclusion}

The relevance of social capital, business economics and drug trafficking is discussed from various angles at each section of the present study. In this study, social capital and business economics were specifically discussed in network terms because drug trafficking groups operate based on such basis. Even though social capital, business economics and illicit drug business have significant discrepancies in regards to legality, they have similar applications in regards to surviving or developing in a highly competitive economic arena. Both legal and illegal organizations are very active. They are changing, developing, and establishing suitable environments to sustain their own organization whether they are legally generating economic transactions for the mutual benefits to society or expanding drug syndicates for personal gain. Either way, the goals of both types of organizations do not significantly affect the procedure of social networking strategies.

In summary, drug trafficking groups are highly fragmented business initiatives based on dynamic supply and demand (Natarajan, 2006) that endeavor to deploy many tactics to transact drug business within their network settings. Further, the technology and economic advances in the last few decades have converted transnational organized crime to more sophisticated and fluid organisms. Both business sector and organized crime syndicates have understood the importance of business economics, market opportunities, limitations and social networking (Kenney, 2007). However, the expansions of drug trafficking organizations differ from legal business organizations due to their clandestine work procedures. In order to deal with such crime syndicates, criminal justice organizations need to understand the specifics related with social network structure of organized crime to better serve crime prevention strategies and law enforcement (Williams, 1998).

The "War on Drugs" armed with appropriate tools and research, can stop the drug trafficking business. But there remain many unanswered questions regarding the development, expansion and operating methods in organized crime syndicates that could be targeted in future research. They include: What are the most frequently used networking and business transactions 
Yeşilyurt, H. (2014). The analysis of social capital and social networking of drug trafficking. International Journal of Human Sciences, 11(1), 280-290. doi: 10.14687/ijhs.v11i1.2758

between transnational organized crime groups? Do law enforcement agencies have enough tools and skills to understand organized crime syndicates in terms of network analysis and social capital? Are the law enforcement agencies as fluid as organized crime groups in implementing their operations or investigations? One thing is clear, understanding social networking in the development of drug trafficking organizations is crucial to development of future strategies.

\section{References}

Abadinsky, H. (2010). Organized crime. CengageBrain. com.

Albanese, J.S. (2004). North American organised crime. Global Crime, 6(1), 8-18.

Andreopoulos, G. J. (Ed.). (2013). Policing Across Borders: Law Enforcement Networks and the Challenges of Crime Control. New York: Springer.

Arias, E.D. (2006). Drugs and democracy in Rio De Janeiro Trafficking, social networks, and public security. North Carolina: The University of North Carolina Press.

Calvó-Armengol, A., \& Zenou, Y. (2004). Social networks and crime decisions: the role of social structure in facilitating delinquent behavior. International Economic Review, 45(3), 939958.

Casteel, S.W. (2001, September). Drug trafficking in the United States. Retrieved April 18, 2005, from http://www.U.S.doj.gov/dea/pubs/intel/01020/index.html

Chalk, P. (2011). The Latin American Drug Trade: Scope, Dimensions, Impact, and Response. Rand Corporation. Pittsburgh, PA:RAND Corporation.

Coleman, J.S. (1988). Social capital in the creation of human capital. American Journal of Sociology, S95-S120.

Cross, R., Parker, A. \& Sasson, L. (2003). Networks in the knowledge economy. New York: Oxford University Press.

Degenhardt, L., \& Hall, W. (2012). Extent of illicit drug U.S. and dependence, and their contribution to the global burden of disease. The Lancet, 379(9810), 55-70.

Drug Distribution/Trafficking (n. d. ). Retrieved April 25, 2005, from http://criminal.findlaw. com/crimes/a-z/drug distribution trafficking.html

Drug Trafficking in the United States (n. d.). Retrieved April 22, 2005, from http://www.dea.gov/concern/drug_trafficking.html

Flap, H., \& Boxman, E. (2001). Getting started: the influence of social capital on the start of the occupational career. In Nan Lin, Karen S. Cook \& Ronald S. Burt (Eds.), Social capital: Theory and research (pp. 159-181). Retrieved from http://www.fss.uu.nl/pubs/hflap/2001gettingstarted.pdf

Fukumi, S. (2013). Cocaine trafficking in Latin America: EU and U.S. policy responses. Burlington, VT: Ashgate Publishing.

Gaines, L. K., Kraska, P. (2003). Drugs, crime and justice. Illinois: Waveland Press.

Granovetter, M.S. (1973). The strength of weak ties. American Journal of Sociology. 78, 1360-1380.

Grootaert, C., \& Van Bastelaer, T. (Eds.). (2002). The role of social capital in development: An empirical assessment. New York:Cambridge University Press.

Harris, K.D. (2010). Organized crime in California (Annual Report to the Legislature). California:California Department of Justice. Kamala. D. Harris. Retrieved from http://oag.ca.gov/sites/all/files/pdfs/publications/org_crime2010.pdf

Jackson, J. L., Herbrink, J. C., \& Jansen, R. W. (1996). Examining criminal organizations: Possible methodologies. Transnational Organized Crime, 2(4), 83-105.

Kappeler, V.E., Potter, G.W., \& Blumberg, M. (2005). Mythology of crime and criminal justice. Illinois: Waveland Press, Inc. 
Yeşilyurt, H. (2014). The analysis of social capital and social networking of drug trafficking. International Journal of Human Sciences, 11(1), 280-290. doi: 10.14687/ijhs.v11i1.2758

Kenney, M. (2007). The architecture of drug trafficking: network forms of organisation in the Colombian cocaine trade. Global Crime, 8(3), 233-259.

Küçükuysal, B. (2012). Drug legalization debate. SDU Faculty of Arts and Sciences, Journal of Social Sciences. 24(December), 215-224.

Lin, N. (2002). Social capital: A theory of social structure and action (Vol. 19). New York: Cambridge University Press.

McCarthy, D.M. (2011). An economic history of organized crime: A national and transnational approach. New York: Routledge.

Mishra, P.P. (Ed.). (2008). Organized crime: from trafficking to terrorism (Vol. 1). Abc-clio.

Morselli, C., Turcotte, M. , \& Tenti, V. (2011). The mobility of criminal groups. Global Crime, 12(3), 165-188.

McIllwain, J. S. (1999). Organized crime: A social network approach. Crime, Law and Social Change, 32(4), 301-323.

Natarajan, M. (2006). Understanding the structure of a large heroin distribution network: A quantitative analysis of qualitative data. Journal of Quantitative Criminology, 22(2), 171-192.

Drug Intelligence Center. (2011). National drug threat assessment (Product No . 2011-Q0317-001). Washington, DC: U. S. Department of Justice. Retrieved from http://www.justice.gov/archive/ndic/pubs44/44849/44849p.pdf

Pearson, G., \& Hobbs, D. (2001) Middle market drug distribution. Home Office, London

Potter, G.W. (1993). Criminal organizations: vice, racketeering, and politics in an American city. Long Grove, Illinois: Waveland Pr Inc.

Putnam, R.D. (2002). Bowling alone: America's declining social capital. Journal of Democracy, 6(1), 65-78.

Schaler, J.A. (1998). Drugs. New York: Promethe: U.S. Books.

Sellens, J.T. (2009). Knowledge, networks and economic activity. Revisiting the network effects in the knowledge economy. UOC Papers-e-Journal on the Knowledge Society, (8). Retrieved from http://www.uoc.edu/uocpapers/8/dt/eng/torrent.pdf

Scott, W.R. (1998). Organizations. New Jersey: Prentice Hall.

United Nations Office on Drugs and Crime, UNODC (2013). World Drug Report 2010. New York, NY: United Nations Publications. Retrieved from http://www.unodc.org/wdr/

Wasserman, S., \& Faust, K. (1999). Testing multi-level, multi-theoretical hypotheses about networks in 21st century organizational forms: An analytic framework and empirical example. Retrieved December 5, 2006.

Wellman, B. (1983). "Network Analysis: Some Basic Principles." In Randall Collins (ed.) Sociological Theory 1983, pp. 155-200. San Francisco: Jossey-Bass.

Williams, Phil Retrieved December 5, 2006, from RAND Web site:http://www.rand. org/pubs/monograph reports/MR1382/MR1382.ch3.pdf

Williams, P. (1998). The nature of drug-trafficking networks. Current History-New York Then Philadelphia, 97, 154-159.

Zhang S., \& Chin, K. (2004). Characteristics of Chinese buman smugglers(Report No:200607). U.S. Department of Justice: National Institute of Justice, United States. 